\title{
Desulfovibrio arcticus sp. nov., a psychrotolerant sulfate-reducing bacterium from a cryopeg
}

Correspondence

Viktoria A. Shcherbakova shcherb@ibpm.pushchino.ru

\author{
Svetlana A. Pecheritsyna, ${ }^{1}$ Elizaveta M. Rivkina, ${ }^{2}$ Vladimir N. Akimov ${ }^{1}$ \\ and Viktoria A. Shcherbakova ${ }^{1}$
}

\author{
${ }^{1}$ Skryabin Institute of Biochemistry and Physiology of Microorganisms, \\ Russian Academy of Sciences, Pushchino, Moscow Region, 142290, Russia \\ ${ }^{2}$ Institute of Physicochemical and Biological Problems in Soil Science, \\ Russian Academy of Sciences, Pushchino, Moscow Region, 142290, Russia
}

\begin{abstract}
A psychrotolerant sulfate-reducing bacterium, designated $\mathrm{B} 15^{\top}$, was isolated from supercooled water brine from within permafrost of the Varandey Peninsula, on the southern coast of the Barents Sea. Cells were Gram-negative, motile vibrions (3.0-4.0×0.4-0.5 $\mu \mathrm{m})$ with a single polar flagellum. The isolate was positive for desulfoviridin as a bisulfite reductase. Strain $\mathrm{B}^{1} 5^{\top} \mathrm{grew}$ at -2 to $28{ }^{\circ} \mathrm{C}$ (optimum $24{ }^{\circ} \mathrm{C}$ ) and with $0-2.0 \% \mathrm{NaCl}$ (optimum $0.2 \%$ ). The isolate used $\mathrm{H}_{2}$ plus acetate, formate, ethanol, lactate, pyruvate and choline as electron donors and used sulfate, sulfite, thiosulfate, elemental sulfur, DMSO and $\mathrm{Fe}^{3+}$ as electron acceptors. Pyruvate and lactate were not fermented in the absence of sulfate. The $G+C$ content of genomic DNA was $55.2 \mathrm{~mol} \%$. Analysis of the 16S rRNA gene sequence showed that the isolate belonged to the genus Desulfovibrio. Its closest relatives were Desulfovibrio idahonensis $\mathrm{CY}^{\top}{ }^{\top}$ (98.8\% $16 \mathrm{~S}$ rRNA gene sequence similarity) and Desulfovibrio mexicanus Lup $1^{\top}(96.5 \%)$. On the basis of genotypic, phenotypic and phylogenetic characteristics, the isolate represents a novel species, for which the name Desulfovibrio arcticus sp. nov. is proposed; the type strain is $\mathrm{B}^{1} 5^{\mathrm{T}}(=\mathrm{VKM}$ $\mathrm{B}-2367^{\mathrm{T}}=\mathrm{DSM} 21064^{\mathrm{T}}$ ).
\end{abstract}

Cryopegs are perennially cryotic layers of unfrozen ground (a part of permafrost) in which freezing is prevented by freezing-point depression due to dissolved solids in the water (Gilichinsky et al., 2005). Cryopegs are located within permafrost marine sediments of the High Arctic at different depths. Highly mineralized Arctic cryopegs have been shown to harbour diverse micro-organisms, including cold-adapted strains (Gilichinsky et al., 2005; Shcherbakova et al., 2005; Bakermans et al., 2006). Viable bacteria of different phylogenetic and physiological groups have been found recently in cryopegs of the Varandey Peninsula, on the southern coast of the Barents Sea, Russia (Pecheritsyna et al., 2007).

A cold-adapted, sulfate-reducing representative of the genus Desulfovibrio, designated $\mathrm{B} 15^{\mathrm{T}}$, was isolated from the water of a cryopeg (mineralization $9.3 \mathrm{~g} \mathrm{l}^{-1}$ ), which was sampled at a depth of $9 \mathrm{~m}$. The sample was taken during the field expedition in 2004 and kept frozen (at $-20{ }^{\circ} \mathrm{C}$ )

\footnotetext{
Abbreviation: AQDS, anthraquinone-2,6-disulfonate.

The GenBank/EMBL/DDBJ accession number for the $16 \mathrm{~S}$ rRNA gene sequence of strain $B 15^{\top}$ is DQ296030.
}

Three supplementary figures and a supplementary table are available with the online version of this paper. for 2 months until analysis. The drilling system and the subsequent procedure of recovering uncontaminated material are described elsewhere (Shi et al., 1997). Enrichment and isolation were performed using basal growth medium [(BGM) containing $\mathrm{l}^{-1}: 0.33 \mathrm{~g} \mathrm{KH}_{2} \mathrm{PO}_{4}, 0.33 \mathrm{~g} \mathrm{KCl}, 5.0 \mathrm{~g}$ $\mathrm{NaCl}, 0.33 \mathrm{~g} \mathrm{NH}_{4} \mathrm{Cl}, 0.33 \mathrm{~g} \mathrm{MgCl}_{2} \cdot 6 \mathrm{H}_{2} \mathrm{O}, 0.33 \mathrm{~g} \mathrm{CaCl}_{2}$, $4.0 \mathrm{~g} \mathrm{Na} \mathrm{SO}_{4}, 0.002 \mathrm{~g}$ resazurin, $10 \mathrm{ml}$ trace element solution SL-10 (medium 320; DSMZ) and $5 \mathrm{ml}$ vitamin solution (Wolin et al., 1963); supplemented prior to inoculation with $25 \mathrm{ml} \mathrm{NaHCO} 3(10 \%$, w/v), $2.5 \mathrm{ml} \mathrm{HCl}$ $(25 \%, \mathrm{v} / \mathrm{v})$ and $10 \mathrm{ml}$ sodium lactate $(20 \%, \mathrm{w} / \mathrm{v})$ per litre]. For enrichment and isolation, the tenfold serial dilution method was used, as described previously (Pecheritsyna et al., 2007). Culture purity was assessed by observing uniform cell types under a phase-contrast microscope and the absence of growth in BGM with $1 \mathrm{~g}$ glucose and $1 \mathrm{~g}$ peptone $1^{-1}$. The pure culture was maintained at $24{ }^{\circ} \mathrm{C}$ in modified BGM $(0.2 \% \mathrm{NaCl})$. Desulfovibrio idahonensis CY $1^{\mathrm{T}}\left(=\mathrm{DSM} 15450^{\mathrm{T}}\right)$ and Desulfovibrio mexicanus Lup $1^{\mathrm{T}}$ $\left(=\mathrm{DSM} 13116^{\mathrm{T}}\right)$, used as reference strains, were grown in DSMZ 63 and 860 media, respectively.

Cells were examined by phase-contrast and electron microscopy as described previously (Shcherbakova et al., 2005). Cells of strain $B 15^{\mathrm{T}}$ were motile vibrions $(3.0-4.0 \times 0.4-$ $0.5 \mu \mathrm{m}$ ), each with a single polar flagellum (Supplementary 
Fig. S1, available in IJSEM Online). The Gram reaction was negative and electron microscopy of sectioned cells revealed a typical Gram-negative cell wall (Supplementary Fig. S1a). Spore formation was not observed.

Strain $B 15^{\mathrm{T}}$ was tested for production of desulfoviridin (Postgate, 1959) with Desulfovibrio desulfuricans VKM B- $1799^{\mathrm{T}}$ and Escherichia coli $\mathrm{K}-12$ as positive and negative controls, respectively. Cytochrome $c$ was analysed by recording the redox difference and $\mathrm{CO}$ difference spectra as described by Widdel (1980). The spectra of the cell extracts exhibited the characteristic absorption bands of desulfoviridin and cytochrome $c$ at $631 \mathrm{~nm}$ and $552 \mathrm{~nm}$, respectively. Acetate was detected as a product of incomplete lactate oxidation by GC (Shcherbakova et al., 2005).

Conditions for growth of strain $\mathrm{B} 15^{\mathrm{T}}$ and reference strains were tested in their respective cultivation media supplemented with $20 \mathrm{mM}$ sodium lactate and $20 \mathrm{mM}$ sulfate, unless otherwise stated. Electron donors were tested with $20 \mathrm{mM}$ sulfate as a terminal electron acceptor and electron acceptors were tested with $20 \mathrm{mM}$ sodium lactate as an electron donor. All tests were performed in triplicate and confirmed by two transfers. Growth was assessed by measuring the changes in $\mathrm{OD}_{580}$ and hydrogen sulfide production (Cline, 1969). $\mathrm{Fe}^{3+}\left(90 \mathrm{mmol} \mathrm{l}{ }^{-1}\right)$ was added as amorphous iron (III) oxide, prepared by titration of acidic $\mathrm{FeCl}_{3}$ solution with $10 \%$ (w/v) $\mathrm{NaOH}$ to $\mathrm{pH}$ 7.0. Reduction of $\mathrm{Fe}^{3+}$ and anthraquinone-2,6-disulfonate (AQDS) was studied as described by Lovley \& Phillips (1986) and Lovley et al. (1996). The effect of temperature was examined at $-2,5,10,18,24,28,37,42$ and $48{ }^{\circ} \mathrm{C}$. The incubation at $-2{ }^{\circ} \mathrm{C}$ was carried out in a cryobath filled with ethylene glycol. The effect of $\mathrm{pH}$ was examined at $\mathrm{pH} 5.5-8.5$ (at intervals of $0.5 \mathrm{pH}$ units) with the $\mathrm{pH}$ adjusted with sterile anaerobic $1 \mathrm{M} \mathrm{HCl}, 10 \%$ (w/v) $\mathrm{NaHCO}_{3}$ or $8 \%(\mathrm{w} / \mathrm{v}) \mathrm{Na}_{2} \mathrm{CO}_{3}$. The effect of $\mathrm{NaCl}$ was examined in DSMZ 63 containing $0,0.1,0.2,0.3,0.5,1.0$, 2.0, 3.0 and $5.0 \%(\mathrm{w} / \mathrm{v}) \mathrm{NaCl}$.

Strain $\mathrm{B} 15^{\mathrm{T}}$ used (mM, unless otherwise stated) $\mathrm{H}_{2}$ plus acetate (20), formate (10), lactate (20), ethanol (10), pyruvate (10) and choline (10) as electron donors in the presence of sulfate, but did not oxidize propionate (10), butyrate (10), valerate (10), methanol (10), acetate (20), propanol (10), butanol (10), glycerol (10), glucose $\left(1 \mathrm{~g} \mathrm{l}^{-1}\right)$, fructose $\left(1 \mathrm{~g} \mathrm{l}^{-1}\right)$, glutamate (10), serine (10), betaine (10), sorbitol (5), malate (10), succinate (10), fumarate (10), proline (10), alanine (10), cysteine (10), glycine (10), Casamino acids $\left(2 \mathrm{~g} \mathrm{l}^{-1}\right)$ or yeast extract $\left(0.5 \mathrm{~g} \mathrm{l}^{-1}\right)$. Fermentative growth was not observed with pyruvate (20), lactate (20), malate (20), fumarate (20), cysteine (10), Casamino acids $\left(1 \mathrm{~g} \mathrm{l}^{-1}\right)$, peptone $\left(1 \mathrm{~g} \mathrm{l}^{-1}\right)$ or glucose $\left(1 \mathrm{~g} \mathrm{l}^{-1}\right)$. Strain $B 15^{\mathrm{T}}$ did not require any vitamins for growth. Yeast extract $\left(0.1-0.5 \mathrm{~g} \mathrm{l}^{-1}\right)$ greatly stimulated growth.

The characteristics of strain $\mathrm{B} 15^{\mathrm{T}}$ and the reference strains are given in Table 1 . Strain $\mathrm{B} 15^{\mathrm{T}}$ and the reference strains used lactate, formate and $\mathrm{H}_{2}$ plus acetate as electron donors in the presence of sulfate and used sulfate (20), sulfite (2), thiosulfate (10), DMSO (10) and elemental sulfur as electron acceptors in the presence of lactate. Strain $\mathrm{B} 15^{\mathrm{T}}$ and $D$. idahonensis $\mathrm{CY}^{\mathrm{T}}$ reduced $\mathrm{Fe}^{3+}$ without visible growth. Strain $\mathrm{B} 15^{\mathrm{T}}$ and D. mexicanus $\mathrm{Lup}^{\mathrm{T}}$ did not use malate (20), fumarate (20) or AQDS (4) as electron acceptors. In contrast to $D$. idahonensis DSM $15450^{\mathrm{T}}$, strain $\mathrm{B} 15^{\mathrm{T}}$ did not

Table 1. Differential characteristics of strain $B 15^{\top}$ and its closest phylogenetic relatives

Strains: 1 , Desulfovibrio arcticus sp. nov. $\mathrm{B} 15^{\mathrm{T}} ; 2$, D. idahonensis $\mathrm{CY} 1^{\mathrm{T}}$; 3, D. mexicanus Lup $1^{\mathrm{T}}$. All data were taken from this study. All strains used $\mathrm{H}_{2}$ plus acetate, formate, lactate and pyruvate as electron donors with sulfate and used sulfate, sulfite, thiosulfate, DMSO and elemental sulfur as electron acceptors with lactate. None of the strains used acetate, propionate, butyrate, valerate, benzoate, methanol, propanol, butanol, glycerol, ethylene glycol, sorbitol or glutamate as electron donors or used nitrate and nitrite as electron acceptors.

\begin{tabular}{|c|c|c|c|}
\hline Characteristic & 1 & 2 & 3 \\
\hline \multicolumn{4}{|l|}{ Cell dimensions $(\mu \mathrm{m})$} \\
\hline Length & $3.0-4.0$ & $1.3-2.5$ & $1.7-2.5$ \\
\hline Width & $0.4-0.5$ & 0.6 & 0.5 \\
\hline Flagella ${ }^{\star}$ & SP & SP & - \\
\hline \multicolumn{4}{|l|}{ Temperature for growth $\left({ }^{\circ} \mathrm{C}\right)$} \\
\hline Range & -2 to 28 & $5-42$ & $18-42$ \\
\hline Optimum & 24 & 28 & 37 \\
\hline \multicolumn{4}{|l|}{$\mathrm{NaCl}$ for growth (\%) } \\
\hline Range & $0-2.0$ & $0-1.0$ & $0-1.0$ \\
\hline Optimum & 0.2 & 0.1 & 0 \\
\hline Optimum $\mathrm{pH}$ for growth & $6.7-7.0$ & 6.5 & 7.2 \\
\hline \multicolumn{4}{|l|}{$\begin{array}{l}\text { Electron donors with } \\
\text { sulphate: }\end{array}$} \\
\hline Fumarate & - & + & - \\
\hline Malate & - & + & - \\
\hline Succinate & - & + & - \\
\hline Ethanol & + & - & - \\
\hline Serine & - & - & + \\
\hline Cysteine & - & - & + \\
\hline Choline & + & - & + \\
\hline Alanine & - & - & + \\
\hline Casamino acids & - & - & + \\
\hline Yeast extract & - & - & + \\
\hline \multicolumn{4}{|l|}{ Substrates fermented: } \\
\hline Pyruvate & - & + & + \\
\hline Lactate & - & - & + \\
\hline \multicolumn{4}{|l|}{$\begin{array}{l}\text { Electron acceptors with } \\
\text { lactate: }\end{array}$} \\
\hline Fumarate & - & + & - \\
\hline AQDS & - & + & - \\
\hline $\mathrm{Fe}^{3+}$ & + & + & - \\
\hline $\begin{array}{l}\text { DNA G }+\mathrm{C} \text { content }(\mathrm{mol} \%) \\
\left(T_{\mathrm{m}}\right)\end{array}$ & 55.2 & $63.2(63.5) \dagger$ & 64.0 (66)末 \\
\hline
\end{tabular}

${ }^{\star} \mathrm{SP}$, Single polar.

$\dagger$ Data in parentheses from Sass et al. (2009) (HLPC method). $\ddagger$ Data in parentheses from Hernandez-Eugenio et al. (2000) (HLPC method). 
grow with fumarate, malate or succinate but grew with ethanol and choline.

The temperature range $\left(-2\right.$ to $\left.28{ }^{\circ} \mathrm{C}\right)$ and optimum $\left(24{ }^{\circ} \mathrm{C}\right)$ for growth of strain $\mathrm{B} 15^{\mathrm{T}}$ differed from those of the reference strains (Supplementary Fig. S2, available in IJSEM Online). Strain $\mathrm{B} 15^{\mathrm{T}}$ grew at $\mathrm{pH}$ 6.0-8.0 (optimum $\mathrm{pH}$ 6.7-7.0) and with $\leqslant 2.0 \% \mathrm{NaCl}$. The reference strains had lower ranges of $\mathrm{NaCl}$ concentration for growth than strain $\mathrm{B} 15^{\mathrm{T}}$ and were mesophilic (optima of 28 and $37{ }^{\circ} \mathrm{C}$ for strains $\mathrm{CY} 1^{\mathrm{T}}$ and Lup $1^{\mathrm{T}}$, respectively), whereas strain $\mathrm{B} 15^{\mathrm{T}}$ was psychrotolerant (growth at $-2{ }^{\circ} \mathrm{C}$; optimum $24{ }^{\circ} \mathrm{C}$ ).

Cellular fatty acids and menaquinones were determined using cells grown at the optimal temperature in DSMZ 63 and harvested during the late exponential growth phase. Lipid extraction, esterification, purification and quantification by GC were performed as described previously (Shcherbakova et al., 2005). Menaquinones were analysed following the procedure of Collins (1985). The fatty acid compositions of strain $\mathrm{B} 15^{\mathrm{T}}$ and the reference strains (Supplementary Table S1, available in IJSEM Online) showed the presence of iso- $\mathrm{C}_{17: 1}$, which is characteristic of the family Desulfovibrionaceae. The dominant fatty acids of strain $\mathrm{B} 15^{\mathrm{T}}$ and the reference strains were $\mathrm{C}_{16: 1} \omega 7 c, \mathrm{C}_{16: 0}$ and anteiso- $\mathrm{C}_{15: 0}$. The major menaquinone in the isolate and the reference strains was $\mathrm{MK}-6\left(\mathrm{H}_{2}\right)$.

DNA was isolated from cell biomass according to Marmur (1961). DNA-DNA hybridization (four replications) was performed as described by De Ley et al. (1970) and modified by Huß et al. (1983) using a Pye Unicam SP 1800 spectrophotometer equipped with a thermoprogrammer and hermetically sealed thermocuvettes. The standard deviations of the hybridization experiments were between 5.5 and $9.0 \%$. DNA-DNA relatedness values of strain $\mathrm{B} 15^{\mathrm{T}}$ with $D$. idahonensis DSM $15450^{\mathrm{T}}$ and D. mexicanus DSM $13116^{\mathrm{T}}$ were 38 and $32 \%$, respectively, and that between $D$. idahonensis DSM $15450^{\mathrm{T}}$ and D. mexicanus DSM $13116^{\mathrm{T}}$ was $29 \%$. The DNA G $+C$ content $\left(T_{\mathrm{m}}\right.$ method) of strain $\mathrm{B} 15^{\mathrm{T}}, D$. idahonensis DSM $15450^{\mathrm{T}}$ and $D$. mexicanus DSM $13116^{\mathrm{T}}$ was $55.2 \pm 0.5,63.2 \pm 0.5$ and $64.0 \pm 0.6 \mathrm{~mol} \%$, respectively. The DNA G+C content measured for D. idahonensis DSM $15450^{\mathrm{T}}$ was close to the value (63.5 mol\%) determined by Sass et al. (2009), whereas that for D. mexicanus DSM $13116^{\mathrm{T}}$ differed from the value (66 $\mathrm{mol} \%)$ reported in the original species description (Hernandez-Eugenio et al., 2000).

For amplification and sequencing of the 16S rRNA gene, DNA was extracted by the method described by Sambrook et al. (1989). The 16S rRNA gene was amplified using the prokaryotic 16S rRNA primers 27F (5'-AGAGTTTGATCCTGGCTCAG-3') and 1492r (5'-TACGGYTACCTTGTTACGATT- $3^{\prime}$ ). PCR products were purified using the Wizard PCR Preps DNA Purification system (Promega). Sequencing reactions were performed using a CEQ Dye Terminator Cycle Sequencing kit and analysed using a CEQ2000 XL automatic sequencer (Beckman Coulter), according to the manufacturer's instructions. A large fragment $(1425 \mathrm{bp})$ of the 16S rRNA gene sequence was obtained from strain $\mathrm{B} 15^{\mathrm{T}}$. The NCBI BLAST utility (Altschul et al., 1997; Benson et al., 1998) was used to identify the closest known relatives of strain $B 15^{\mathrm{T}}$. Nucleotide sequences were aligned in CLUSTAL X (Chenna et al., 2003; Thompson et al., 1997). TREECON (Van de Peer \& De Wachter, 1994) and MEGA version 4 (Tamura et al., 2007) were used for phylogenetic analysis with the neighbour-joining method (Saitou \& Nei, 1987). The percentages of replicate trees where associated taxa formed the same clusters were calculated from 1000 replicates using the bootstrap test (Felsenstein, 1985). Evolutionary distances were computed using the Jukes-Cantor method (Juke \& Cantor, 1969). The neighbour-joining tree (Fig. 1) and the maximum-likelihood tree (Supplementary Fig. S3, available in IJSEM Online) had similar topologies; the only difference

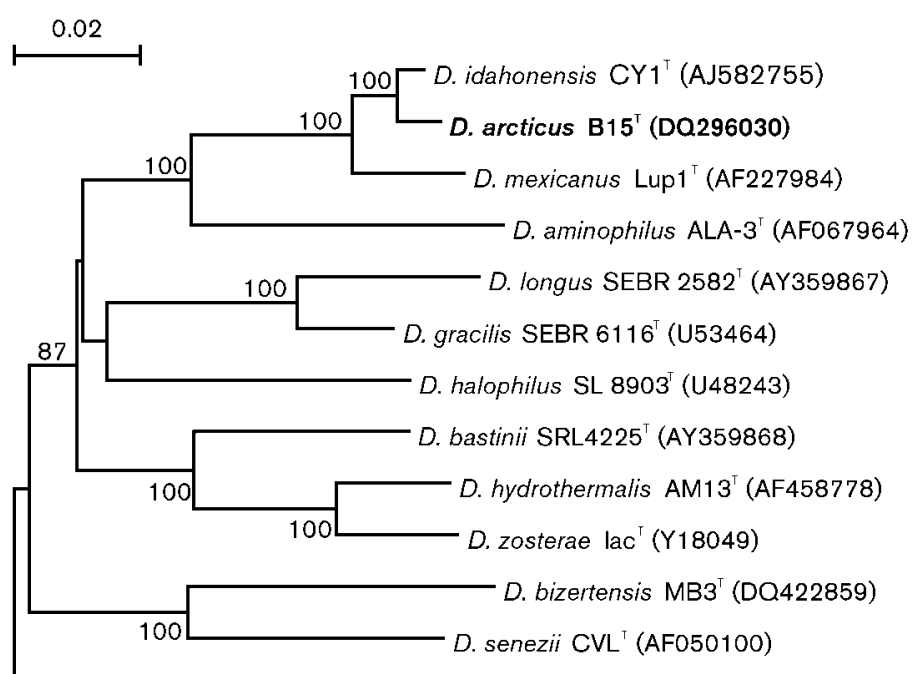

D. desulfuricans Adams Essex $6^{\top}$ (AF192153)
Fig. 1. Neighbour-joining phylogenetic tree based on 16S rRNA gene sequences showing the position of strain $B 15^{\top}$ in the genus Desulfovibrio. Bootstrap values ( $>50 \%$ ) based on 1000 replicates are shown at branch nodes. Escherichia coli K-12 MG1655 (accession no. L10328) was used as the outgroup (not shown). Bar, 0.02 substitutions per nucleotide position. 
was the position of Desulfovibrio halophilus SL $8903^{\mathrm{T}}$. The closest relatives of strain $\mathrm{B} 15^{\mathrm{T}}$ were $D$. idahonensis $\mathrm{CY} 1^{\mathrm{T}}$ (98.8\% 16S rRNA gene sequence similarity) and $D$. mexicanus Lup $1^{\mathrm{T}}$ (96.5\%).

Dissimilatory sulfate reduction is the most important anaerobic mineralization pathway in cold marine habitats (Jørgensen, 1982; Knoblauch et al., 1999a). Recently, psychrophilic and psychrotolerant sulfate-reducing bacteria from permanently cold habitats have been described as representatives of new taxa (Knoblauch et al., 1999b; Vandieken et al., 2006a, b; Vatsurina et al., 2008). Arctic cryopegs are characterized by a high sulfate content $(0.62-$ $3.84 \mathrm{~g} \mathrm{l}^{-1}$ ), but our previous attempts to isolate sulfatereducing bacteria from this habitat have failed. Strain $\mathrm{B} 15^{\mathrm{T}}$ is the first-reported sulfate-reducing bacterium from a cryopeg within the Arctic permafrost and is able to grow and generate sulfide at $-2{ }^{\circ} \mathrm{C}$.

The chemotaxonomic, genotypic and phenotypic data strongly support the recognition of strain $\mathrm{B} 15^{\mathrm{T}}$ as a representative of a novel species within the genus Desulfovibrio. The name Desulfovibrio arcticus sp. nov. is proposed.

\section{Description of Desulfovibrio arcticus sp. nov.}

Desulfovibrio arcticus (arc'ti.cus. L. masc. adj. arcticus northern, Arctic, referring to the region of isolation).

Cells are Gram-negative vibrions $(3.0-4.0 \times 0.4-0.5 \mu \mathrm{m})$ and motile by a single polar flagellum. Cells contain desulfoviridin. Utilizes $\mathrm{H}_{2}$ plus acetate, formate, pyruvate, lactate, choline and ethanol as electron donors and carbon sources in the presence of sulfate. Pyruvate and lactate are not fermented in the absence of sulfate. Utilizes sulfate, sulfite, thiosulfate, elemental sulfur, DMSO and $\mathrm{Fe}^{3+}$ as terminal electron acceptors in the presence of lactate. Grows at -2 to $28{ }^{\circ} \mathrm{C}$ (optimum $24{ }^{\circ} \mathrm{C}$ ), at pH 6.0-8.0 (optimum $\mathrm{pH}$ 6.7-7.0), but not at $\mathrm{pH} 5.5$ or 8.5 , and with $0-2.0 \% \mathrm{NaCl}$ (optimum $0.2 \%$ ). Growth is stimulated by the addition of $0.1-0.5 \mathrm{~g}$ yeast extract $l^{-1}$. The predominant fatty acids $(>10 \%)$ are $\mathrm{C}_{16: 1} \omega 7 c, \mathrm{C}_{16: 0}$ and anteiso- $\mathrm{C}_{15: 0}$. The predominant isoprenoid quinone is MK-6 $\left(\mathrm{H}_{2}\right)$.

The type strain is $\mathrm{B} 15^{\mathrm{T}}\left(=\mathrm{VKM} \mathrm{B}-2367^{\mathrm{T}}=\mathrm{DSM} 21064^{\mathrm{T}}\right)$, isolated from a cryopeg within permafrost on the Varandey Peninsula, on the southern coast of the Barents Sea, Russia. The DNA G + C content of the type strain is $55.2 \mathrm{~mol} \%$.

\section{Acknowledgements}

We are grateful to Dr Tatyana Abashina (Skryabin Institute of Biochemistry and Physiology of Microorganisms, RAS, Pushchino, Russia) for her help with electron microscropy, Dr Ekaterina Detkova (Winogradsky Institute of Microbiology, RAS, Moscow, Russia) for the determination of $\mathrm{G}+\mathrm{C}$ content and Dr Yuri Osipov (Bakulev Center of Cardiovascular Surgery, Moscow, Russia) for the analysis of fatty acids. The study was supported by RFBR (project no. 06-0449011) and the 'Molecular and Cell Biology' of the Russian Academy of Sciences programme (grant no. 01200957822).

\section{References}

Altschul, S. F., Madden, T. L., Schäffer, A. A., Zhang, J., Zhang, Z., Miller, W. \& Lipman, D. J. (1997). Gapped BLAST and PSI-BLAST: a new generation of protein database search programs. Nucleic Acids Res 25, 3389-3402.

Bakermans, C., Ayala-del-Río, H. L., Ponder, M. A., Vishnivetskaya, T., Gilichinsky, D., Thomashow, M. F. \& Tiedje, J. M. (2006). Psychrobacter cryohalolentis sp. nov. and Psychrobacter arcticus sp. nov., isolated from Siberian permafrost. Int J Syst Evol Microbiol 56, 1285-1291.

Benson, D. A., Boguski, M. S., Lipman, D. J., Ostell, J. \& Ouellette, B. F. (1998). GenBank. Nucleic Acids Res 26, 1-7.

Chenna, R., Sugawara, H., Koike, T., Lopez, R., Gibson, T. J., Higgins, D. G. \& Thompson, J. D. (2003). Multiple sequence alignment with the CLUSTAL series of programs. Nucleic Acids Res 31, 3497-3500.

Cline, J. D. (1969). Spectrophotometric determination of hydrogen sulfide in natural waters. Limnol Oceanogr 14, 454-458.

Collins, M. D. (1985). Analysis of isoprenoid quinones. Methods Microbiol 18, 329-366.

De Ley, J., Cattoir, H. \& Reynaerts, A. (1970). The quantitative measurement of DNA hybridization from renaturation rates. Eur $J$ Biochem 12, 133-142.

Felsenstein, J. (1985). Confidence limits on phylogenies: an approach using the bootstrap. Evolution 39, 783-791.

Gilichinsky, D., Rivkina, E., Bakermans, C., Shcherbakova, V., Petrovskaya, L., Ozerskaya, S., Ivanushkina, N., Kochkina, G., Laurinavichuis, K. \& other authors (2005). Biodiversity of cryopegs in permafrost. FEMS Microbiol Ecol 53, 117-128.

Hernandez-Eugenio, G., Fardeau, M.-L., Patel, B. K. C., Macarie, H., Garcia, J.-L. \& Ollivier, B. (2000). Desulfovibrio mexicanus sp. nov., a sulfate-reducing bacterium isolated from an upflow anaerobic sludge blanket (UASB) reactor treating cheese wastewaters. Anaerobe 6, 305312.

Huß, V. A. R., Festl, H. \& Schleifer, K. H. (1983). Studies on the spectrophotometric determination of DNA hybridization from renaturation rates. Syst Appl Microbiol 4, 184-192.

Jørgensen, B. B. (1982). Mineralization of organic matter in the sea bed - the role of sulphate reduction. Nature 296, 643-645.

Juke, T. H. \& Cantor, C. R. (1969). Evolution of protein molecules. In Mammalian Protein Metabolism, vol. 3, pp. 21-132. Edited by H. N. Munro. New York: Academic Press.

Knoblauch, C., Jørgensen, B. B. \& Harder, J. (1999a). Community size and metabolic rates of psychrophilic sulfate-reducing bacteria in Arctic marine sediments. Appl Environ Microbiol 65, 4230-4233.

Knoblauch, C., Sahm, K. \& Jørgensen, B. B. (1999b). Psychrophilic sulfate-reducing bacteria isolated from permanently cold arctic marine sediments: description of Desulfofrigus oceanense gen. nov., sp. nov., Desulfofrigus fragile sp. nov., Desulfofaba gelida gen. nov., sp. nov., Desulfotalea psychrophila gen. nov., sp. nov. and Desulfotalea arctica sp. nov. Int J Syst Bacteriol 49, 1631-1643.

Lovley, D. R. \& Phillips, E. J. P. (1986). Availability of ferric iron for microbial reduction in bottom sediments of the freshwater tidal Potomac River. Appl Environ Microbiol 52, 751-757.

Lovley, D. R., Coates, J. D., Blunt-Harris, E. L., Phillips, E. J. P. \& Woodward, J. C. (1996). Humic substances as electron acceptors for microbial respiration. Nature 382, 445-448.

Marmur, J. (1961). A procedure for the isolation of deoxyribonucleic acid from micro-organisms. J Mol Biol 3, 208-218.

Pecheritsyna, S. A., Shcherbakova, V. A., Kholodov, A. L., Akimov, V. N., Abashina, T. N., Suzina, N. E. \& Rivkina, E. M. (2007). 
Microbiological analysis of cryopegs from the Varandey Peninsula, Barents Sea. Microbiology 76, 614-620.

Postgate, J. A. (1959). A diagnostic reaction of Desulphovibrio desulphuricans. Nature 183, 481-482.

Saitou, N. \& Nei, M. (1987). The neighbor-joining method: a new method for reconstructing phylogenetic trees. Mol Biol Evol 4, 406425.

Sambrook, J., Fritsch, E. F. \& Maniatis, T. (1989). Molecular Cloning: a Laboratory Manual, 2nd edn. Cold Spring Harbor, NY: Cold Spring Harbor Laboratory.

Sass, H., Ramamoorthy, S., Yarwood, C., Langner, H., Schumann, P., Kroppenstedt, R. M., Spring, S. \& Rosenzweig, R. F. (2009). Desulfovibrio idahonensis sp. nov., sulfate-reducing bacteria isolated from a metal(loid)-contaminated freshwater sediment. Int J Syst Evol Microbiol 59, 2208-2214.

Shcherbakova, V. A., Chuvilskaya, N. A., Rivkina, E. M., Pecheritsyna, S. A., Laurinavichius, K. S., Suzina, N. E., Osipov, G. A., Lysenko, A. M., Gilichinsky, D. A. \& Akimenko, V. K. (2005). Novel psychrophilic anaerobic spore-forming bacterium from the overcooled water brine in permafrost: description Clostridium algoriphilum sp. nov. Extremophiles 9, 239-246.

Shi, T., Reeves, R. H., Gilichinsky, D. A. \& Friedmann, E. I. (1997). Characterization of viable bacteria from Siberian permafrost by $16 \mathrm{~S}$ rDNA sequencing. Microb Ecol 33, 169-179.

Tamura, K., Dudley, J., Nei, M. \& Kumar, S. (2007). MEGA4: Molecular Evolutionary Genetics Analysis (MEGA) software version 4.0. Mol Biol Evol 24, 1596-1599.
Thompson, J. D., Gibson, T. J., Plewniak, F., Jeanmougin, F. \& Higgins, D. G. (1997). The CLUSTAL_X windows interface: flexible strategies for multiple sequence alignment aided by quality analysis tools. Nucleic Acids Res 25, 4876-4882.

Van de Peer, Y. \& De Wachter, R. (1994). TREECON for Windows: a software package for the construction and drawing of evolutionary trees for the Microsoft Windows environment. Comput Appl Biosci 10, 569-570.

Vandieken, V., Knoblauch, C. \& Jørgensen, B. B. (2006a). Desulfovibrio frigidus sp. nov. and Desulfovibrio ferrireducens sp. nov., psychrotolerant bacteria isolated from Arctic fjord sediments (Svalbard) with the ability to reduce Fe(III). Int J Syst Evol Microbiol 56, 681-685.

Vandieken, V., Knoblauch, C. \& Jørgensen, B. B. (2006b). Desulfotomaculum arcticum sp. nov., a novel spore-forming, moderately thermophilic, sulfate-reducing bacterium isolated from a permanently cold fjord sediment of Svalbard. Int J Syst Evol Microbiol 56, 687-690.

Vatsurina, A., Badrutdinova, D., Schumann, P., Spring, S. \& Vainshtein, M. (2008). Desulfosporosinus hippei sp. nov., a mesophilic sulfate-reducing bacterium isolated from permafrost. Int J Syst Evol Microbiol 58, 1228-1232.

Widdel, F. (1980) Anaerober Abbau von Fettsäuren und benzoesäure durch neu isolierte Arten Sulfat-reduzierender Bakterien. PhD thesis, Gottingen University, Gottingen, Germany.

Wolin, E. A., Wolin, M. J. \& Wolfe, R. S. (1963). Formation of methane by bacterial extracts. J Biol Chem 238, 2882-2886. 